\title{
Isolation of antibacterial compounds from Quercus dilatata L. through bioassay guided fractionation
}

\author{
Maryam Jamil', Ihsan ul Haq², Bushra Mirza ${ }^{1 *}$ and Mazhar Qayyum³
}

\begin{abstract}
Background: Four medicinal plants (Chrozophora hierosolymitana Spreng, Chrysanthemum leucanthemum L., Ephedra gerardiana Wall. ex Stapf, and Quercus dilatata L.) used by indigenous healers to treat various infectious diseases were selected for the present study. The major objective of the present study was isolation and characterization of antimicrobial components from the crude plant extracts using bioassay guided fractionation.

Methods: Seven methanolic extracts of the four plants were screened to identify any antimicrobial agents present in them. The active crude plant extract was fractionated first by solvent partitioning and then by HPLC. Characterization of the active fractions was done by using spectrophotometer.

Results: All the seven methanolic extracts showed low antifungal activity, however, when these extracts were tested for antibacterial activity, significant activity was exhibited by two extracts. The extract of aerial parts of $Q$. dilatata was most active and therefore, was selected for further analysis. Initially fractionation was done by solventsolvent partitioning and out of six partitioned fractions, ethanol fraction was selected on the basis of results of antibacterial activity and phytochemical analysis. Further, fractionation was carried out by RP- HPLC and purified active subfractions were characterized by comparing their absorption spectra with that of the known natural products isolated from the plants of Quercus genus.
\end{abstract}

Discussion and conclusion: The results suggest that this is the first report of the isolated antibacterial compounds from this genus.

Keywords: Absorption spectrum, Antibacterial activity, Phytochemical analysis, RP-HPLC analysis, Solvent partitioning

\section{Background}

Development of multi-drug resistance in pathogenic microbes and parasites and non-availability of safe antifungal drugs for systemic mycoses necessitates a search for new antimicrobial substances from other sources, including plants. The present study also aims at isolation of new natural antimicrobial compounds from some selected plants through bioassay guided isolation. Bioassay-guided isolation integrates the processes of separation of compounds in a mixture, using various analytical methods, with results obtained from biological testing. The process begins with testing an extract to confirm its activity, followed by crude separation of the compounds in the matrix

\footnotetext{
* Correspondence: bushramirza@qau.edu.pk

'Department of Biochemistry, Quaid i Azam University, Islamabad, Pakistan Full list of author information is available at the end of the article
}

and testing the crude fractions. Further fractionation is carried out on the fractions that are found to be active at a certain concentration threshold, whereas the inactive fractions are set aside or discarded. The process of fractionation and biological testing is repeated until pure compound(s) are obtained. Structural identification of the pure compound then follows. This methodology precludes overlooking novel compounds that are often missed in studies that only identify those compounds with which the investigator is familiar. Several natural compounds have been isolated by using this methodology [1-3]. The present study was designed to use bioassay fractionation for isolation of antimicrobial agents from four selected plants including Chrozophora hierosolymitana, Chrysanthemum leucanthemum, Ephedra gerardiana and Quercus dilatata. For initial screening, these four selected plants were tested 
against seven fungal and six bacterial strains covering a broad range of microbes.

Chrozophora hierosolymitana is commonly known as Dyer's croton. Chrozophora is genus of the family Euphorbiaceae. Harraz and Abdel-Aziz [4] reported the central analgesic effect of Chrozophora sp. Chrozophora species are used in traditional medicine for the treatment of diverse ailments [5]. For example antifungal [6] and antiyeast [7] activities have been reported from the genus Chrozophora. It has also been reported to serve as a remedy for intestinal pain, for conjunctivitis as well as cicatrizant $[8,9]$.

Chrysanthemum leucanthemum is commonly known as ox eye daisy. Chrysanthemum is a genus of family Asteraceae. Wild Chrysanthemum is used as an antipyretic and anti-inflammatory herb and is prescribed to clear away heat, detoxicate, subdue swelling, dissolve lumps and treat respiratory infections [10]. Hou and Jin [11] reported the use of wild Chrysanthemum for dizziness, headaches, hypertension, fullness in the head and blood shot, swollen, and painful eyes due to hyperactivity of liver (Liver-fire).

Ephedra gerardiana is commonly known as Ma Huang. Ephedra is a genus of non flowering seed plants belonging to the family Ephedraceae. Plants of the Ephedra genus have traditionally been used by indigenous people for a variety of medicinal purposes, including treatment of asthma, hay fever, and common cold [12], used in decoction as diuretic, cholagogue, antiinflammatory and vulnerary. Some species of this genus have been used to cure urinary infections [13].

Quercus dilatata is commonly known as holly oak. Quercus is a plant genus of the family Fagaceae. It is used as an astringent and antidiarrhoeal [14]. The stem bark is used to clean foul sores. The seeds are used in the treatment of diarrhoea, menorrhagia and gastrointestinal hypertrophy. It has been reported that different species of Quercus possess antibacterial activity $[15,16]$, antioxidant activity [17-19] and gastroprotective effect [20]. The galls of Quercus are used particularly for the treatment of wounds or burns associated with bacterial infections [21].

\section{Methods}

\section{Plant material and extraction}

In this study, four plants (Chrozophora hierosolymitana Spreng, Chrysanthemum leucanthemum L., Ephedra gerardiana Wall. ex Stapf and Quercus dilatata L.) were collected from different regions of Pakistan. These were identified following by Professor Dr. Mir Ajab Khan and voucher specimens were deposited at the Herbarium of Pakistan, Quaid i Azam University, Islamabad. The plant tissues were macerated at room temperature for two weeks with methanol and filtered. The solvent was removed by rotary evaporator under reduced pressure and low temperature. Extraction of each plant part (leaf, stem and root) was carried out separately and all necessary precautions were adopted to avoid cross contamination. Seven crude extracts of these plants (leaf, stem and root extracts of $C$. hierosolymitana, aerial parts of $C$. leucanthemum, stem and root extracts of $E$. gerardiana and aerial parts of Q. dilatata) were prepared. All the extracts were stored at $-20^{\circ} \mathrm{C}$.

\section{Antifungal assay}

Antifungal activity against seven fungal strains (Fusarium moniliformes, Fusarium solani, Aspergillus niger, Aspergillus fumigatus, Aspergillus flavus, Alternaria sp. and Mucor sp.) was determined using agar tube dilution method as reported earlier [22]. All fungal strains were grown on 6.5\% SDA (Sabouraud dextrose agar, $\mathrm{pH} 5.7$ ) at $28^{\circ} \mathrm{C}$ and preserved at $4{ }^{\circ} \mathrm{C}$ in refrigerator. Screw capped test tubes containing Sabouraud dextrose agar (SDA) medium (4ml) were autoclaved at $121^{\circ} \mathrm{C}$ for 15 minutes. The tubes were allowed to cool at $50^{\circ} \mathrm{C}$ and non solidified SDA was loaded with $66.6 \mu \mathrm{l}$ of plant extracts pipeted from the stock solution $(24 \mathrm{mg} / \mathrm{ml}$ in DMSO) to make $400 \mu \mathrm{g} / \mathrm{ml}$ final concentration. Tubes were then allowed to solidify at room temperature in slanting position. Each slant was inoculated with equal amount of fungal culture of size $4 \mathrm{~mm}$ diameter and incubated at $28^{\circ} \mathrm{C}$ for 7-10 days. The media supplemented with DMSO and Turbinafine $(200 \mu \mathrm{g} / \mathrm{ml})$ were used as negative and positive control respectively. The fungal growth was determined by measuring linear growth $(\mathrm{mm})$ and compared with negative control to get the \% age inhibition by using the following formula.

$$
\begin{aligned}
& \% \text { age of fungal inhibition } \\
& =100-\frac{\text { Fungal growth }(\mathrm{mm}) \text { in sample }}{\text { Fungal growth }(\mathrm{mm}) \text { in control }} \times 100
\end{aligned}
$$

\section{Antibacterial assay}

Antibacterial assay was carried out as reported earlier [23]. All plant extracts and fractions were tested against three gram-positive bacterial strains i.e., Bacillus subtilis (ATCC 6633), Micrococcus leuteus (ATCC 10240), Staphylococcus aureus (ATCC 6538)] and three gram negative ones i.e., Escherichia coli (ATTCC 1522), Salmonella setubal (ATCC 19196) and Bordetella bronchiseptica (ATCC 4617).

\section{Agar well diffusion method}

The agar well diffusion method, was applied for the determination of inhibition zones and minimum inhibitory concentration (MIC) of plant extracts and partitioned fractions. Briefly, $0.75 \mathrm{ml}$ of the broth culture containing $10^{8}$ colony forming units (CFU) per $\mathrm{ml}$ of the test strain was added to $75 \mathrm{ml}$ of nutrient agar medium at $45^{\circ} \mathrm{C}$, mixed well, and then poured into a $14 \mathrm{~cm}$ sterile petriplate. The medium was allowed to solidify, and 8-mm 
wells were dug with a sterile metallic borer. Eight concentrations of extract, two solutions for positive control (Roxithromycin and Cefixime-USP, one for each) and one for negative control (DMSO) were applied to each petriplate. These plates were incubated at $37^{\circ} \mathrm{C}$. After 24 hrs of incubation the diameter of the clear zones, showing no bacterial growth, around each well was measured. Triplicate plates were prepared for each extract. Mean clear zone of these plates was calculated with standard error. The minimum inhibitory concentration (MIC) was determined by agar well diffusion [24] method. Serial dilutions of each extract $(1 \mathrm{mg} / \mathrm{ml})$ in DMSO were prepared to obtain a $0.1-0.9 \mathrm{mg} / \mathrm{ml}$ concentration range. A $100 \mu \mathrm{L}$ of each dilution of the extract was introduced into wells in nutrient agar plates pre inoculated with test bacterial strains. The extracts were allowed to diffuse at room temperature before incubation at $37^{\circ} \mathrm{C}$ for $24 \mathrm{~h}$.

\section{Disc diffusion method}

Disc diffusion method was applied for the determination of inhibition zones and minimum inhibitory concentration (MIC) of fractions. Filter paper discs of $6 \mathrm{~mm}$ diameter containing only one concentration of each fraction i.e., $1 \mathrm{mg} / \mathrm{mL}$ in methanol were tested against the six bacterial strains. A $20 \mu \mathrm{L}$ of the prepared concentration of each fraction was applied to a disc. The solvent was evaporated and the disc was placed on nutrient agar plates pre inoculated with test bacterial strains.

\section{Fraction preparation}

\section{Solvent partitioning}

The crude extract of the most active antibacterial plant was subjected to bio-guided fractionation by solubilisation in water and sequential partition with hexane $(5 \times 400 \mathrm{~mL})$, ethyl acetate $(5 \times 400 \mathrm{~mL})$, chloroform $(3 \times 400 \mathrm{~mL})$, acetone $(5 \times 400 \mathrm{~mL})$, ethanol $(5 \times 400 \mathrm{~mL})$ and $50 \%$ methanol $(3 \times 400 \mathrm{~mL})$ as indicated in Figure 1 . Each fraction thus obtained, including the final hydromethanol fraction, was evaporated to dryness and subjected to antibacterial assay.

\section{HPLC analysis of ethanol fraction}

The highly active partitioned fraction (ethanol) was analyzed by HPLC system consisting of Agilent 1200 series preparative pump coupled with UV diode array detector. Optimization of mobile phase and wave length for RPHPLC analysis of ethanol fraction of (A) Q. dilatata was carried out using Zorbax SB-C18 analytical column $(4.6 \times 150 \mathrm{~mm}, 5 \mu \mathrm{m}$ particle size, Agilent, Germany) . Sample was prepared in methanol at concentration of 25 $\mathrm{mg} / \mathrm{mL}$. The sample was filtered quickly through a $0.2 \mu \mathrm{m}$ syringe filter. The injection volume was $20 \mu \mathrm{L}$. Different mobile phases used for optimization with the isocratic flow kept constant at $1 \mathrm{~mL} / \mathrm{min}$ were as follows:

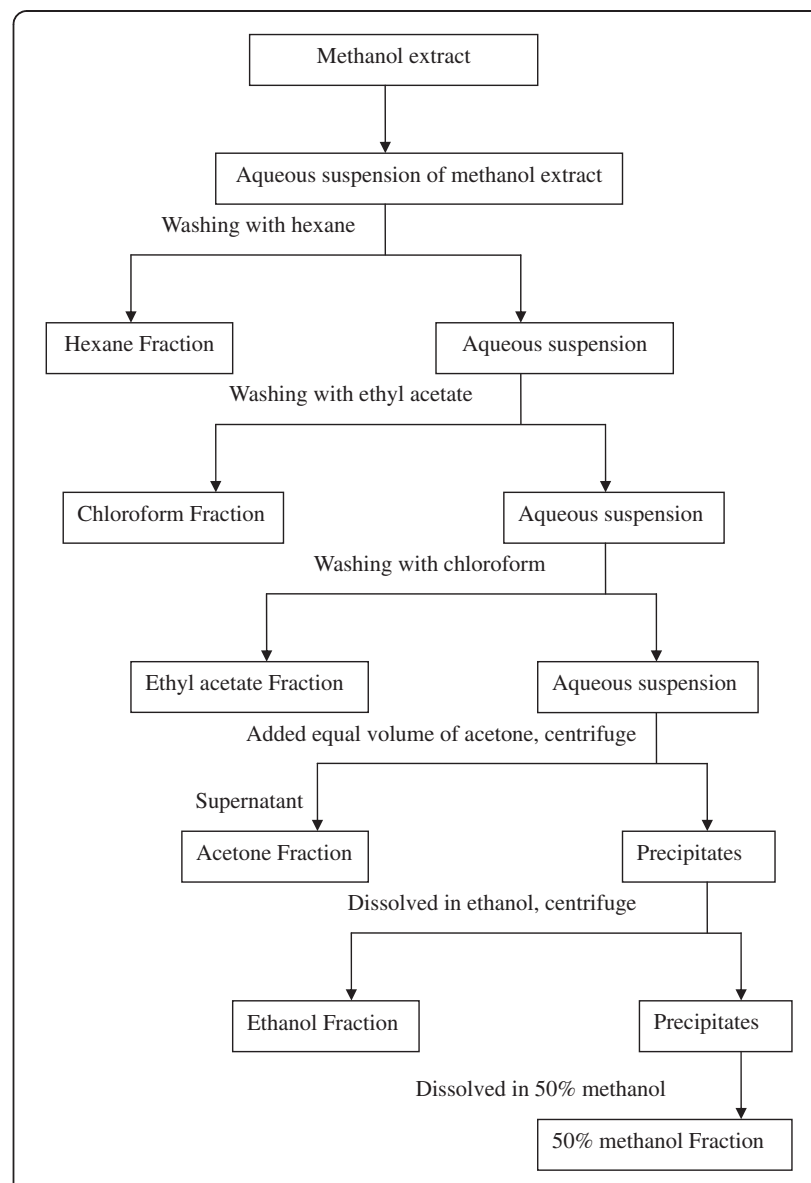

Figure 1 Scheme of fractions preparation.

a) Methanol: water: acetonitrile: acetic acid (90:100:10:2).

b) Acetonitrile: water (85: 15)

c) Acetonitrile: methanol: water (75: 10: 15)

d) Methanol: acetonitrile: acetic acid (90: 10: 1)

e) Acetonitrile: methanol: ethyl acetate: toluene (59: 30: 10: 1$)$ with $0.1 \%$ triethylamine.

f) Acetonitrile: water (60:40)

g) Acetonitrile: methanol (70: 30)

A UV diode array detector was set at five different wave lengths i.e. $230 \mathrm{~nm}, 235 \mathrm{~nm}, 240 \mathrm{~nm}, 245 \mathrm{~nm}$ and 250nm. Acetonitrile: methanol (70: 30) and 230nm wavelength was selected for the preparative HPLC on the basis of results of analytical HPLC.

\section{Preparative HPLC}

RP- HPLC analysis of ethanol fraction of (A) Q. dilatata was done using LiChrospher 100 RP-C18 preparative column $(25 \times 250 \mathrm{~mm}, 5 \mu \mathrm{m}$ particle size, Merck, Germany). The sample was prepared in methanol at a concentration of $50 \mathrm{mg} / \mathrm{mL}$. The injection volume was 1 
mL. Acetonitrile: methanol (70: 30) and 230nm wavelength was used for the preparative HPLC. The isocratic flow was kept constant at $10 \mathrm{~mL} / \mathrm{min}$.

RP- HPLC analysis of purified fractions was done using Zorbax SB-C18 analytical column $(4.6 \times 150 \mathrm{~mm}, 5 \mu \mathrm{m}$ particle size, Agilent, Germany).

\section{Characterization of the purified active component}

Thirty micrograms of the purified active component and each of four standards (Quercitrin, Gallic acid, Rutin and Ascorbic acid) were dissolved in $3 \mathrm{~mL}$ of methanol to prepare $10 \mu \mathrm{g} / \mathrm{mL}$ concentration. Absorption spectra of the purified active component and each of four standards (Quercitrin, Gallic acid, Rutin and Ascorbic acid) were obtained at 210-900nm by using spectrophotometer coupled with UV-diode array detector (DAD).

\section{Phytochemical analysis}

Qualitative phytochemical analysis of partitioned fractions was carried out by using standard procedures to identify the constituents as described by Edeoga et al. [25] and Parekh and Chanda [26].

Alkaloids To identify presence of alkaloids, $4 \mathrm{~mL}$ of $1 \%$ $\mathrm{HCl}$ was added to the $0.25 \mathrm{~g}$ of plant extract and then warmed and filtered. To $1 \mathrm{ml}$ filtrate 6 drops of Mayor's reagents/Dragendroff reagent was added separately. Creamish precipitate/orange precipitate indicated the presence of respective alkaloids.

Saponins: (Frothing test) To detect saponins, $0.5 \mathrm{~g}$ of the plant extract was boiled in $5 \mathrm{~mL}$ of distilled water. After cooling it was shaken vigorously to produce stable persistent froth.

Anthraquinones To check presence of anthraquinones, $0.5 \mathrm{~g}$ of the plant extract was boiled with $3 \mathrm{~mL}$ of $1 \% \mathrm{HCl}$ and filtered. To filtrate, $2 \mathrm{~mL}$ of benzene was added and was shaken well. The benzene layer was removed and few drops of $10 \% \mathrm{NH}_{4} \mathrm{OH}$ were added. Formation of pink, violet or red color indicated the presence of anthraquinones.

Couramins For couramins analysis, $0.5 \mathrm{~g}$ of moistened plant extract was taken in a test tube and covered with a filter paper moistened with $0.1 \mathrm{~N} \mathrm{NaOH}$. The test tube was placed, for few minutes, in boiling water. Then the filter paper was removed and examined in UV light for yellow florescence to indicate the presence of couramins.

Terpenoids (Liebermann-Burchard reaction): To identify presence of terpenoids, $0.5 \mathrm{~g}$ of the plant extracxt was dissolved in $2 \mathrm{~mL}$ of chloroform and filtered. To filtrate, equal volume of acetic acid and a drop of conc. $\mathrm{H}_{2} \mathrm{SO}_{4}$ were added. Blue-green ring indicated the presence of terpenoids.

Flavonoids, Flavones To detect flavanoids and flavones, $0.5 \mathrm{~g}$ of the extract was washed with petroleum ether. The defatted residue was dissolved in $20 \mathrm{~mL}$ of $80 \%$ of ethanol and filtered. The filtrate was used for the following test;

a) About $3 \mathrm{ml}$ of the filtrate was mixed with $4 \mathrm{ml}$ of $1 \%$ $\mathrm{AlCl}_{3}$ in $\mathrm{MeOH}$ in a test tube. Formation of yellow colour indicated the presence of flavanols, flavones.

b) About $3 \mathrm{ml}$ of the filtrate was mixed with $4 \mathrm{ml}$ of $1 \%$ $\mathrm{KOH}$. A dark yellow colour indicated the presence of flavonoids.

Tannins To test tannins, $0.25 \mathrm{~g}$ of plant extract was boiled in $10 \mathrm{~mL}$ of distilled water and filterd. Then $1 \%$ $\mathrm{FeCl}_{3}$ was added to the filtrate. Browrish green or a blueblack colouration indicated the presence of tannins.

Phlobatannins Deposition of a red precipitate when $0.25 \mathrm{~g}$ of plant extract was boiled with $5 \mathrm{~mL}$ of $1 \%$ aqueous hydrochloric acid was taken as evidence for the presence of phlobatinnins.

Cardiac Glycosides: (Keller - Kiliani Test) To detect cardiac glycosides, $2 \mathrm{~mL}$ of glacial acetic acid and few drops of $1 \% \mathrm{FeCl}_{3}$ were added to $0.5 \mathrm{~g}$ of plant extract. Then it was underlayed with $1 \mathrm{~mL}$ of conc. $\mathrm{H}_{2} \mathrm{SO}_{4}$. Green-blue color indicated the presence of cardiac glycosides.

\section{Results}

\section{Antifungal assay}

All of the seven crude methanol extracts were tested against seven fungal strains Linear growth inhibition was observed. All the plant extracts showed low antifungal activity against all the seven fungal strains (Table 1). Effect of interaction of the plant extract and the fungal strain remained significant at $\mathrm{P}<0.05$.

\section{Antibacterial activity of crude plant extracts}

Antibacterial activity of all the seven crude plant extracts was carried out against six bacterial strains. Our results showed that only two ((R) C. hierosolymitana (A) and $Q$. dilatata) out of the seven plant extracts showed antibacterial activity. Plant extract of (A) Q. dilatata was effective against all the bacterial strains tested at all the concentrations (Table 2). Plant extract of (R) C. hierosolymitana showed activity against three bacterial strains (M. leuteus, B. bronchiseptica, S. Setubal) at the concentrations $5-25 \mathrm{mg} / \mathrm{mL}$ (Table 3). Interaction effect of the plant extract, concentration and the bacterial strain was highly significant at $\mathrm{P}<0.05$. (A) $\mathrm{Q}$. dilatata showed the largest zone of inhibition at $25 \mathrm{mg} / \mathrm{mL}$ against $B$. 
Table 1 Antifungal activity of crude plant extracts against seven fungal strains

\begin{tabular}{|c|c|c|c|c|c|c|c|}
\hline \multirow[t]{2}{*}{ Plant extracts } & \multicolumn{7}{|c|}{ Percentage inhibition in linear growth } \\
\hline & A. niger & A. fumigatus & A. flavus & F. moni & F. solani & Mucor sp. & Alternaria sp. \\
\hline (L) C. hierosolymitana & $\begin{array}{l}\text { 22.08 fghijklm } \\
\pm 2.2\end{array}$ & $\begin{array}{l}2.89^{9 r} \\
\pm 2.61\end{array}$ & $\begin{array}{l}32.73^{\text {cdef }} \\
\pm 1\end{array}$ & $\begin{array}{l}23.48^{\text {efghijklm }} \\
\pm 2\end{array}$ & $\begin{array}{l}18.33^{\text {ghijklmno }} \\
\pm 3.3\end{array}$ & $\begin{array}{l}7.14^{\text {opqr }} \\
\pm 3.3\end{array}$ & $\begin{array}{l}28.26^{\text {cdefghi }} \\
\pm 5.6\end{array}$ \\
\hline (S) C. hierosolymitana & $\begin{array}{l}9.09^{\text {nopqr }} \\
\pm 1.5\end{array}$ & $\begin{array}{l}13.77^{\mathrm{jl} \text { kmnopqr }} \\
\pm 1.92\end{array}$ & $\begin{array}{l}27.27^{\text {cdefghi }} \\
\pm 3.1\end{array}$ & $\begin{array}{l}16.67^{\text {hijklmnop }} \\
\pm 7.6\end{array}$ & $\begin{array}{l}6.67^{\text {opqr }} \\
\pm \pm 1.7\end{array}$ & $\begin{array}{l}14.29^{\mathrm{jk} m n o p q r} \\
\pm \pm 7.4\end{array}$ & $\begin{array}{l}38.04^{c} \\
\pm \pm 5.6\end{array}$ \\
\hline (R) C. hierosolymitana & $\begin{array}{l}34.63^{\text {cde }} \\
\pm \pm 1.9\end{array}$ & $\begin{array}{l}13.04^{\mathrm{klmnopqr}} \\
\pm \pm 3.3\end{array}$ & $\begin{array}{l}27.27^{\text {cdefghi }} \\
\pm \pm 4.2\end{array}$ & $\begin{array}{l}30.3^{\text {cdefg }} \\
\pm \pm 3.8\end{array}$ & $\begin{array}{l}6.67^{\text {opqr }} \\
\pm \pm 1.7\end{array}$ & $\begin{array}{l}7.14^{\text {opqr }} \\
\pm 4.6\end{array}$ & $\begin{array}{l}25^{\text {defghijk }} \\
\pm 8.6\end{array}$ \\
\hline (A) C. leucanthemum & $\begin{array}{l}28.57^{\text {cdefgh }} \\
\pm 1.5\end{array}$ & $\begin{array}{l}28.26^{\text {cdefgh }} \\
\pm 2.5\end{array}$ & $\begin{array}{l}27.27^{\text {cdefghi }} \\
\pm 4.8\end{array}$ & $\begin{array}{l}34.09^{\text {cdef }} \\
\pm 4.7\end{array}$ & $\begin{array}{l}18.33^{\text {ghijklmno }} \\
\pm 9.3\end{array}$ & $\begin{array}{l}14.29^{\mathrm{jklmnopqr}} \\
\pm 3.6\end{array}$ & $\begin{array}{l}34.78^{\text {cde }} \\
\pm 3.7\end{array}$ \\
\hline (S) E. gerardiana & $\begin{array}{l}28.57^{\text {cdefgh }} \\
\pm 0.75\end{array}$ & $\begin{array}{l}25.36^{\text {defghij }} \\
\pm 0.7\end{array}$ & $\begin{array}{l}20^{\text {ghijklmn }} \\
\pm 8.3\end{array}$ & $\begin{array}{l}14.39^{\mathrm{jklmonopq}} \\
\pm 7.2\end{array}$ & $\begin{array}{l}8.33^{\text {nopqr }} \\
\pm 10\end{array}$ & $\begin{array}{l}28.57^{\text {cdefgh }} \\
\pm 4.6\end{array}$ & $\begin{array}{l}2.17^{r} \\
\pm 3.7\end{array}$ \\
\hline (R) E. gerardiana & $\begin{array}{l}22.08^{\text {fghijklm }} \\
\pm 1.3\end{array}$ & $\begin{array}{l}23.91^{\text {efghijkl }} \\
\pm 2.2\end{array}$ & $\begin{array}{l}53.94^{\mathrm{b}} \\
\pm 4.4\end{array}$ & $\begin{array}{l}19.69^{\text {ghijklmn }} \\
\pm 4.6\end{array}$ & $\begin{array}{l}5^{\text {pqr }} \\
\pm 2.9\end{array}$ & $\begin{array}{l}15.71^{\mathrm{ijk} / m n o p} \\
\pm 0.8\end{array}$ & $\begin{array}{l}36.96^{\text {cd }} \\
\pm \pm 2.2\end{array}$ \\
\hline (A) Q. dilatata & $\begin{array}{l}22.08^{\text {fghijklm }} \\
\pm 1.3\end{array}$ & $\begin{array}{l}2.17^{r} \\
\pm 4.5\end{array}$ & $\begin{array}{l}27.27^{\text {cdefghi }} \\
\pm 4.5\end{array}$ & $\begin{array}{l}25.76^{\text {defghij }} \\
\pm 11\end{array}$ & $\begin{array}{l}11.67^{\text {mnopqr }} \\
\pm 4.4\end{array}$ & $\begin{array}{l}3.33^{\text {qr }} \\
\pm 1.3\end{array}$ & $\begin{array}{l}11.96^{\text {Imnopqr }} \\
\pm 4.9\end{array}$ \\
\hline Terbinafine & $100^{a} \pm 0$ & $100^{\mathrm{a}} \pm 0$ & $100^{\mathrm{a}} \pm 0$ & $100^{a} \pm 0$ & $100^{\mathrm{a}} \pm 0$ & $100^{\mathrm{a}} \pm 0$ & $100^{a} \pm 0$ \\
\hline
\end{tabular}

*The data represents the mean values of three replicates. ${ }^{* *}$ Letters ranging from a to $r$ indicate respective Least Significant Difference rank orders of mean values. Values with similar letters are not significantly different from each other at $p>0.05$.

bronchiseptica MIC value of both the extracts which showed antibacterial activity was determined. MIC values are shown in Table 4.

\section{Antibacterial activity and phytochemical analysis of partitioned fractions}

Antibacterial activity of all the six partitioned fractions of (A) Q. dilatata (hexane, ethyl acetate, chloroform, acetone, ethanol and 50\% methanol) was carried out against six bacterial strains. Our results showed that four of the six partition fractions i.e. ethyl acetate, acetone, ethanol and 50\% methanol had antibacterial activity against all the bacterial strains tested (Table 5). However the most active partitioned fraction was ethanol as it showed largest zone of bacterial inhibition (14.3-16.7mm). Effect of interaction of two factors i.e. plant extracts and bacterial strains remained significant $(\mathrm{P}<0.05)$. Ethanol fraction showed highest zone of inhibition against S. Setubal.

Phytochemical analysis of the partitioned fractions showed the presence of different classes of the compound in different fractions. Results are given in the Table 6 . Results showed that alkaloids were present in the acetone, ethanol and 50\% methanol partitioned fractions at varying levels. However the ethanol partitioned fraction was

Table 2 Activity of (A) Q. dilatata against six bacterial strains

\begin{tabular}{|c|c|c|c|c|c|c|}
\hline \multirow[b]{2}{*}{ Conc } & \multicolumn{6}{|c|}{ Zone of inhibition $(\mathrm{mm}) \pm$ S.E } \\
\hline & E. coli & S. aur & B. sub & M. leu & B. Bro & S. setubal \\
\hline 1 & $9.3 \pm 0.333$ & $9.7 \pm 0.33$ & $9.7 \pm 0.33$ & $10.2 \pm 0.34$ & $11.2 \pm 0.17$ & $9.3 \pm 0.33$ \\
\hline 2 & $11.1 \pm 0.1$ & $11.3 \pm 0.67$ & $11.3 \pm 0.88$ & $11.5 \pm 0.53$ & $12.8 \pm 0.44$ & $11.5 \pm 0.76$ \\
\hline 5 & $12.4 \pm 0.21$ & $13.3 \pm 0.67$ & $13.5 \pm 0.79$ & $12.9^{\text {opqrst }} \pm 0.95$ & $15.7^{\text {efghij }} \pm 1.03$ & $13^{\text {opqrs }} \pm 0.78$ \\
\hline 7 & $13.6 \pm 0.09$ & $15.2 \pm 0.83$ & $13.7 \pm 0.33$ & $13.6^{\text {Imnopqrs }} \pm 0.83$ & $16.8^{\text {defgh }} \pm 1.2$ & $13.6^{\text {Imnopqrs }} \pm 0.8$ \\
\hline 10 & $14.7 \pm 0.15$ & $16.2 \pm 0.83$ & $14.5 \pm 0.47$ & $14.9^{\text {ghijklmno }} \pm 0.95$ & $18^{\mathrm{cd}} \pm 1.73$ & $14.2^{\mathrm{ijklmnopq}} \pm 0.77$ \\
\hline 15 & $15.4 \pm 0.15$ & $17.2 \pm 0.8$ & $15.7 \pm 0.67$ & $15.2^{\text {efghijklm }} \pm 0.83$ & $19.8^{\mathrm{bc}} \pm 1.17$ & $15.1^{\text {fghijklmn }} \pm 0.87$ \\
\hline 20 & $16.3 \pm 0.15$ & $18.9 \pm 1.1$ & $17.2 \pm 0.83$ & $16.4^{\text {defgh }} \pm 0.75$ & $21.5^{\mathrm{ab}} \pm 1.47$ & $16.2^{\text {defghi }} \pm 0.97$ \\
\hline 25 & $17 \pm 0.26$ & $19.8 \pm 1.2$ & $18 \pm 1$ & $17^{\mathrm{def}} \pm 0.82$ & $22.7^{\mathrm{a}} \pm 1.73$ & $17.1^{\text {def }} \pm 1.05$ \\
\hline$R$ & $15.3 \pm 0.88$ & $27.1 \pm 0.93$ & $11.7 \pm 0.33$ & $11.5 \pm 0.29$ & $33 \pm 1$ & $11.7 \pm 0.57$ \\
\hline $\mathrm{C}$ & $35.2 \pm 0.44$ & $38.6 \pm 3.4$ & $33.3 \pm 0.33$ & $31.8 \pm 1.32$ & $20.3 \pm 0.33$ & $32.5 \pm 0.79$ \\
\hline E. coli:- & Escherichia coli & B. sub:- & Bacillus subtillus & B. bron:- & Bordetella bronc & tica \\
\hline S. aur:- & Staphylococcus aureus & M. leu:- & Micrococcus luteus & S. set:- & Salmonella setub & \\
\hline $\mathrm{C}$ & Cefixime & $R$ & Roxithromycin & Conc & Concentrations & \\
\hline
\end{tabular}

The data represents the mean values of three replicates \pm represents standard deviation.

Letters ranging from $d$ to $w$ indicate respective Least Significant Difference rank orders of mean values. Values with similar letters are not significantly different from each other at $\mathrm{p}>0.05$. 
Table 3 Activity of (R) C. hierosolymitana against six bacterial strains

\begin{tabular}{|c|c|c|c|c|c|c|}
\hline \multirow[t]{2}{*}{ Conc. } & \multicolumn{6}{|c|}{ Zone of inhibition (mm) } \\
\hline & M. leu & S. aur & B. sub & E. coli & B. Bro & S. set \\
\hline 1 & - & - & - & - & - & - \\
\hline 2 & - & - & - & - & - & - \\
\hline 5 & $9.27^{w} \pm 0.27$ & - & - & - & $9.5^{\mathrm{vw}} \pm 0.29$ & $11.5^{\text {stuv }} \pm 0.09$ \\
\hline 7 & $10.6^{\mathrm{uvw}} \pm 0.32$ & - & - & - & $10.8^{\text {turw }} \pm 0.17$ & $13.1^{\text {nopqrs }} \pm 0.07$ \\
\hline 10 & $12.4^{\text {qrstu }} \pm 0.35$ & - & - & - & $12.1^{\text {rstu }} \pm 0.09$ & $13.9^{\mathrm{klmnopqr}} \pm 0.07$ \\
\hline 15 & $12.7^{\text {pqrst }} \pm 0.32$ & - & - & - & $13.17^{\text {mnopqrs }} \pm 0.17$ & $14.6^{\text {hijklmnop }} \pm 0.06$ \\
\hline 20 & $14.1^{\mathrm{jklmnopqr}} \pm 0.2$ & - & - & - & $14.7^{\text {hijklmnop }} \pm 0.3$ & $16.3^{\text {defgh }} \pm 0.17$ \\
\hline 25 & $15.3^{\text {efghijkl }} \pm 0.17$ & - & - & - & $15.7^{\text {efghijk }} \pm 0.33$ & $17.2^{\text {de }} \pm 0.03$ \\
\hline$R$ & $11.5 \pm 0.29$ & $27.1 \pm 0.93$ & $11.7 \pm 0.33$ & $15.3 \pm 0.88$ & $33 \pm 1$ & $11.7 \pm 0.57$ \\
\hline C & $31.8 \pm 1.32$ & $38.6 \pm 3.4$ & $33.3 \pm 0.33$ & $35.2 \pm 0.44$ & $20.3 \pm 0.33$ & $32.5 \pm 0.79$ \\
\hline E. coli:- & Escherichia coli & B. sub:- & Bacillus subtillus & B. bron:- & Bordetella bronchiseptica & \\
\hline S. aur:- & Staphylococcus aureus & M. leu:- & Micrococcus luteus & S. set:- & Salmonella setuball & \\
\hline$C$ & Cefixime & $R$ & Roxithromycin & Conc & Concentrations & \\
\hline
\end{tabular}

The data represents the mean values of three replicates \pm represents standard deviation.

Letters ranging from $d$ to $w$ indicate respective Least Significant Difference rank orders of mean values. Values with similar letters are not significantly different from each other at $p>0.05$.

Table 4 MIC of (A) Q. dilatata and (R) C. hierosolymitana against six bacterial strains

Plant extracts

Minimum inhibition concentration $(\mu \mathrm{g} / \mathrm{mL})$

M. leu S. aur B. sub E. coli B. bro S. set

\begin{tabular}{lllllll}
\hline (A) Q. dilatata & 400 & 500 & 300 & 200 & 300 & 500 \\
\hline (R) C. hierosolymitana & 4000 & - & - & - & 4000 & 3000 \\
\hline
\end{tabular}

particularly strongly positive for alkaloids. In addition to alkaloids it contained tannins and saponins as well.

Considering most active nature and presence of maximum alkaloids, ethanol partitioned fraction was selected for further purification by using HPLC.

\section{HPLC fractionation}

By using analytical HPLC, different mobile phases were used for optimization of conditions for fractionation with the isocratic flow kept constant at $1 \mathrm{~mL} / \mathrm{min}$. Ethanol partitioned fraction was resolved in maximum peaks by using acetonitrile: methanol (70: 30) as mobile phase at 230nm. Therefore, this mobile phase was selected for the fractionation of ethanol partitioned fraction. When ethanol partitioned fraction was eluted by using acetonitrile: methanol (70: 30) as mobile phase, seven peaks were observed at $230 \mathrm{~nm}$. These seven fractions were collected at different retention times.

Table 5 Activity of partitioned fractions against six bacterial strains

\begin{tabular}{|c|c|c|c|c|c|c|}
\hline \multirow{2}{*}{$\begin{array}{l}\text { Partitioned } \\
\text { fractions }\end{array}$} & \multicolumn{6}{|c|}{ Zone of inhibition (mm) } \\
\hline & E. coli & S. aurs & B. sub & M. leu & B. bron & S. set \\
\hline (A) Q. dilatata & $9.3^{\prime} \pm 0.333$ & $9.7^{\mathrm{kl}} \pm 0.33$ & $9.7^{\mathrm{kl}} \pm 0.33$ & $10.2^{\mathrm{jkl}} \pm 0.34$ & $11.2^{\text {ghij }} \pm 0.17$ & $9.3^{1} \pm 0.33$ \\
\hline Hexane & - & - & - & - & - & - \\
\hline Ethyl acetate & $11.5^{\text {fghi }} \pm 0.28$ & $11.2^{\text {ghij }} \pm 0.2$ & $10.7^{\text {hijk }} \pm 0.3$ & $9.7^{k l} \pm 0.3$ & $10.7^{\text {hijk }} \pm 0.3$ & $10^{\mathrm{kl}} \pm 0.5$ \\
\hline Chloroform & - & - & - & - & - & - \\
\hline Acetone & $12.5^{\mathrm{ef}} \pm 0.3$ & $13.9^{d} \pm 0.1$ & $13.5^{\mathrm{de}} \pm 0.28$ & $14^{\mathrm{d}} \pm 0.5$ & $13.7^{d} \pm 0.8$ & $12.3^{f} \pm 0.3$ \\
\hline Ethanol & $16^{\mathrm{ab}} \pm 0.6$ & $16.17^{\mathrm{ab}} \pm 0.17$ & $14.3^{\mathrm{cd}} \pm 0.7$ & $15.2^{b c} \pm 0.6$ & $16.17^{a b} \pm 0.6$ & $16.7^{a} \pm 0.3$ \\
\hline $50 \%$ methanol & $10.5^{\mathrm{ijk}} \pm 0.3$ & $11.5^{\text {fghi }} \pm 0.28$ & $11.7^{\text {fghi }} \pm 0.2$ & $11.5^{\text {fghi }} \pm 0.3$ & $12.5^{\mathrm{ef}} \pm 0.5$ & $12^{f g} \pm 0.28$ \\
\hline$R$ & $13.5 \pm 0.3$ & $25.4 \pm 0.3$ & $11.2 \pm 0.4$ & $10.8 \pm 0.4$ & $31.5 \pm 0.8$ & $10.5 \pm 0.3$ \\
\hline C & $32.8 \pm 0.4$ & $35.9 \pm 0.6$ & $31.8 \pm 0.2$ & $29.6 \pm 0.4$ & $18.17 \pm 0.4$ & $29.5 \pm 0.5$ \\
\hline E. coli:- & Escherichia coli & B. sub:- & Bacillus subt & & B. bron:- & Bordetella bronchiseptica \\
\hline S. aur:- & Staphylococcus aureus & M. leu:- & Micrococcus & & S. set:- & Salmonella setuball \\
\hline C & Cefixime & $\mathrm{R}$ & Roxithromyc & & Conc & Concentrations \\
\hline
\end{tabular}

The data represents the mean values of three replicates \pm represents standard deviation. Letters ranging from a to $\mathrm{k}$ indicate respective Least Significant Difference rank orders of mean values. Values with similar letters are not significantly different from each other at $\mathrm{p}>0.05$. 
Table 6 Phytochemical analysis of partitioned fractions

\begin{tabular}{|c|c|c|c|c|c|c|c|}
\hline \multicolumn{2}{|c|}{ Class of compounds } & \multirow{2}{*}{ n Hexane } & \multirow{2}{*}{ Ethyl acetate } & \multirow{2}{*}{ Chloroform } & \multirow{2}{*}{$\begin{array}{l}\text { Acetone } \\
++\end{array}$} & \multirow{2}{*}{$\begin{array}{l}\text { Ethanol } \\
+++\end{array}$} & \multirow{2}{*}{$\begin{array}{l}50 \% \text { methanol } \\
+\end{array}$} \\
\hline Alkaloids & Mayer's reagent & & & & & & \\
\hline & Dragendorff's reagent & - & - & - & ++ & +++ & + \\
\hline \multicolumn{2}{|l|}{ Saponins } & + & - & + & + & ++ & ++ \\
\hline \multicolumn{2}{|c|}{ Anthraquinones } & + & - & - & - & - & - \\
\hline \multicolumn{2}{|c|}{ Coumarins } & - & - & - & - & - & - \\
\hline \multicolumn{2}{|c|}{ Terpenoids } & Blue ring in green colour & Blue ring in green colour & - & - & - & - \\
\hline \multicolumn{2}{|c|}{ Flavonoids, Flavones, } & Yellow & Yellow & - & - & - & - \\
\hline \multicolumn{2}{|c|}{ Hydrolysable tannins } & - & ++ & - & ++ & +++ & ++ \\
\hline \multicolumn{2}{|c|}{ Phlobatannins } & - & - & - & - & - & - \\
\hline \multicolumn{2}{|c|}{ Cardiac Glycosides } & Green blue colour & Green blue colour & - & - & - & - \\
\hline
\end{tabular}

Table 7 Antibacterial activity of subfractions against six bacterial strains

\begin{tabular}{|c|c|c|c|c|c|c|}
\hline \multirow[t]{2}{*}{ Sub fractions } & \multicolumn{6}{|c|}{ Zone of inhibition(mm) } \\
\hline & M. leu & S. aur & B. sub & E. coli & B. bro & S. set \\
\hline AM3a & - & - & - & - & - & - \\
\hline $\mathrm{AM} 3 \mathrm{~b}$ & $24 \pm 0.05$ & $28 \pm 0.05$ & $29 \pm 0.03$ & $26 \pm 0.06$ & $24 \pm 0.04$ & $30 \pm 0.03$ \\
\hline $\mathrm{AM} 3 \mathrm{C}$ & $20 \pm 0.05$ & $24 \pm 0.04$ & $23 \pm 0.1$ & $24 \pm 0.07$ & $20 \pm 0.03$ & $24 \pm 0.02$ \\
\hline C & $31 \pm 0.07$ & $31 \pm 0.2$ & $25 \pm 0.1$ & $33 \pm 0.06$ & $25 \pm 0.1$ & $25 \pm 0.5$ \\
\hline $\mathrm{R}$ & $12 \pm 0.1$ & $23 \pm 0.07$ & $9 \pm 0.06$ & $11 \pm 0.2$ & $19 \pm 0.05$ & $10 \pm 0.1$ \\
\hline E. coli:- & Escherichia coli & B. sub:- & Bacillus subtillus & B. bron:- & \multicolumn{2}{|c|}{ Bordetella bronchiseptica } \\
\hline S. aur:- & Staphylococcus aureus & M. lut:- & Micrococcus luteus & S. set:- & \multicolumn{2}{|c|}{ Salmonella setuball } \\
\hline C & Cefixime & $\mathrm{R}$ & Roxithromycine & & & \\
\hline
\end{tabular}

The data represents the mean values of three replicates \pm represents standard deviation.

\section{Antibacterial activity of the fractions}

Antibacterial activity of all the seven HPLC fractions (AM1, AM2, AM3, AM4, AM5, AM6 and AM7) was carried out against six bacterial strains using disc diffusion assay. Our results showed that only one of the seven fractions i.e. AM3 had antibacterial activity against all the bacterial strains tested i.e., B. subtilis $(9.5 \mathrm{~mm})$, M. leuteus (9mm), S. aureus $(9.3 \mathrm{~mm})$, E. coli $(9 \mathrm{~mm})$, S. setubal $(10.1 \mathrm{~mm})$ and B. bronchiseptica $(8 \mathrm{~mm})$. AM3 showed highest antibacterial activity against $S$. setubal. This active fraction was eluted with acetonitrile: methanol (70: 30). Three peaks were observed at $230 \mathrm{~nm}$. Three subfractions were collected at different retention times.

To test antibacterial activity of all the three sub fractions (AM3a, AM3b and AM3c) of fraction AM3, subfractions were dissolved in methanol. AM3a was not soluble in any solvent, while the other two subfractions AM3b and AM3c had antibacterial activity against all the bacterial strains tested (Table 7). AM3b showed highest antibacterial activity against $S$. setubal. MIC values of both the active fractions which showed antibacterial activity were determined (Table 8).

Purity of the two active subfractions AM3b and AM3c was further checked by analytical RP- HPLC analysis and both the fractions showed single peak chromatogram (Figure 2, Figure 3).

\section{Characterization of purified active component}

Purified active subfractions were characterized on the basis of absorption spectrum. The results showed that these two fractions contain independent constituents. Absorption spectra of active subfractions were compared with the absorption spectrum of known compounds previously isolated from the same genus (Figure 4 and Figure 5).

Table 8 MIC of active subfraction against six bacterial strains

\begin{tabular}{lllllll}
\hline Fractions & \multicolumn{6}{l}{ Minimum inhibition concentration $(\boldsymbol{\mu g} / \mathbf{m L})$} \\
\cline { 2 - 7 } & E. coli & S. aur & B. sub & M. leu & B. bro & S. set \\
\hline AM3b & 90 & 100 & 100 & 90 & 300 & 70 \\
\hline AM3c & 200 & 300 & 500 & 200 & 500 & 500 \\
\hline Cefixime & 30 & 10 & 50 & 50 & 80 & 50 \\
\hline Roxithromycine & 800 & 100 & 600 & 600 & 70 & 600 \\
\hline
\end{tabular}




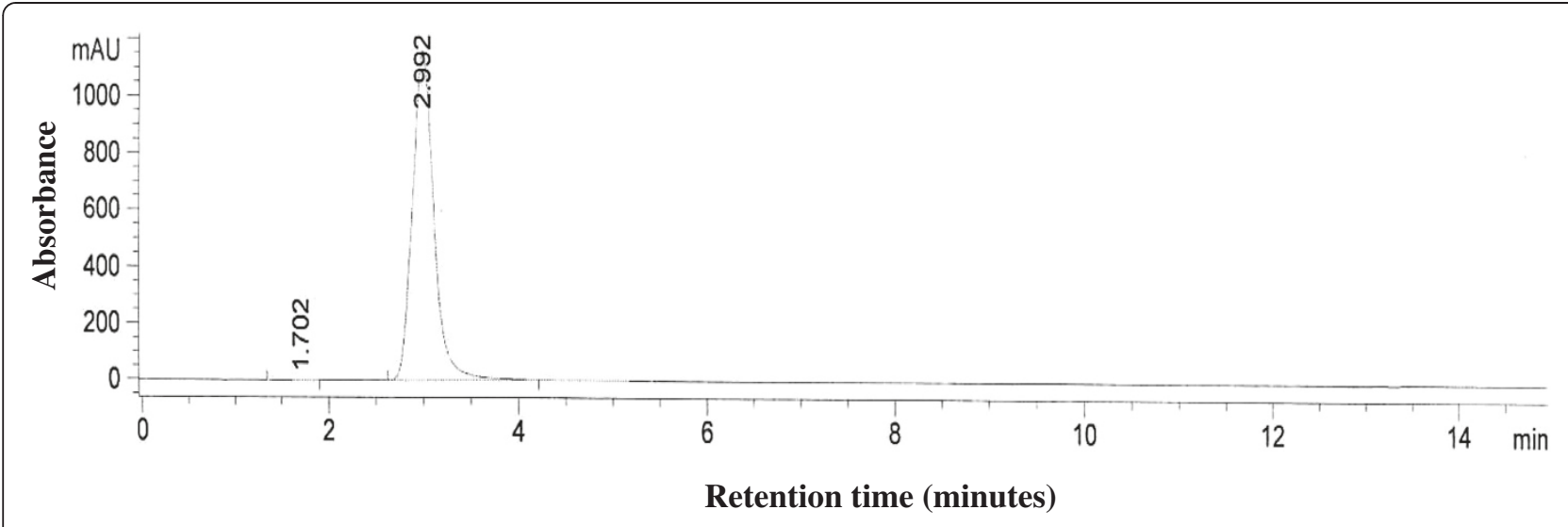

Figure 2 Preparative HPLC Chromatogram obtained for AM3b fraction showing single peak at 2.992 min.

\section{Discussion}

Initial screening of plants for possible active natural products typically begins by using crude aqueous or alcohol extraction and can be followed by various organic extraction methods. However, nearly all of the identified antimicrobial components from plants are aromatic or saturated organic compounds, they are often obtained through initial ethanol or methanol extraction [27]. Therefore, in the present study, for the preparation of all the seven crude extracts, methanol was used as extraction solvent. For initial screening, these seven crude methanol extracts were tested against seven fungal and six bacterial strains covering a broad range of microbes. All the extracts showed low level of antifungal activity. However, antibacterial assay of the crude methanolic extracts showed that only two extracts; aerial parts of $Q$. dilatata and roots of $C$. hierosolymitana had antibacterial activity. The extract of aerial parts of $Q$. dilatata was found highly effective against all the bacterial strains tested i.e., E. coli, B. subtilus, S. aureus, M. luteus,
B. bronchiseptica, and S. setubal while root extract of $C$. hierosolymitana showed antibacterial activity against only three bacterial strains i.e., M. luteus, B. bronchiseptica, and S. setubal. Previously, there have been some reports of the antibacterial and antifungal activities of different species of Quercus [28-31]. However, ours is the first report of antimicrobial activity of $Q$. dilatata.

Based on the results of initial screening the methanol extract of $Q$. dilatata was subjected to bio-guided fractionation by solubilisation in water and sequential partition with different solvents with increasing polarity; hexane, chloroform, ethyl acetate, acetone, ethanol and $50 \%$ methanol yielding six fractions. All the fractions were subjected to antibacterial assay. Four of the six partitioned fractions i.e. ethyl acetate, acetone, ethanol and $50 \%$ methanol showed antibacterial activity against all the bacterial strains tested whereas the hexane and chloroform extracts were inactive. Highest antibacterial activity was shown by ethanol fraction. Phytochemical analysis of partitioned fractions showed the presence of

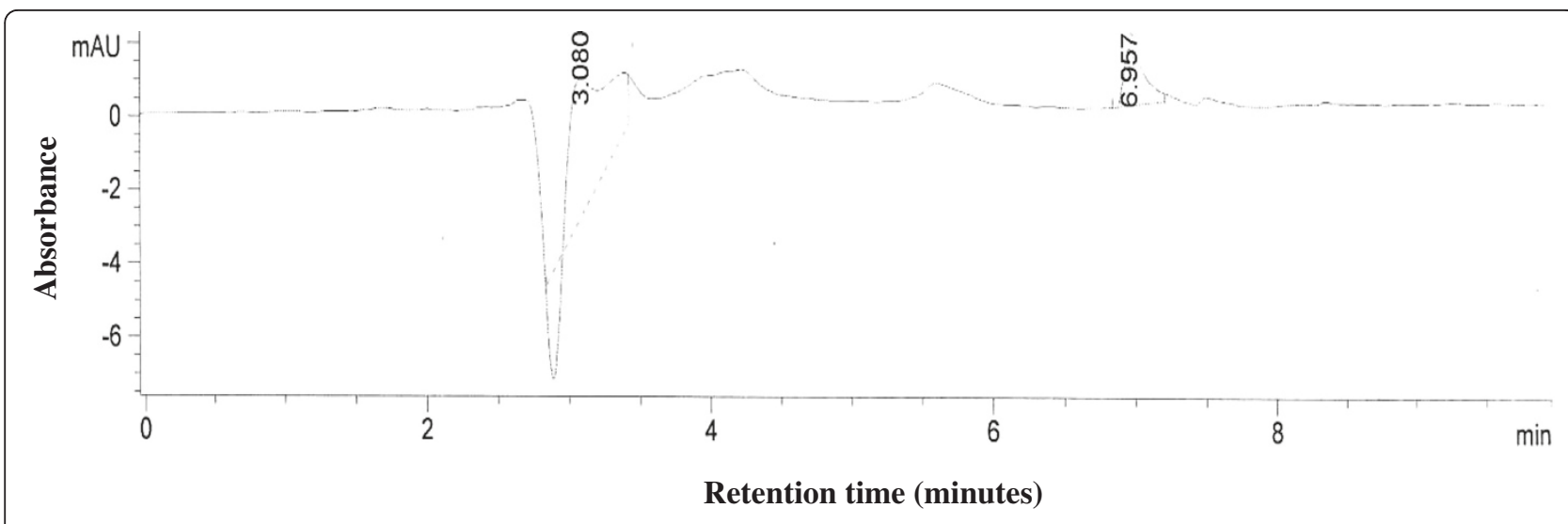

Figure 3 Preparative HPLC Chromatogram obtained for AM3C fraction showing single peak at 6.957 min. 


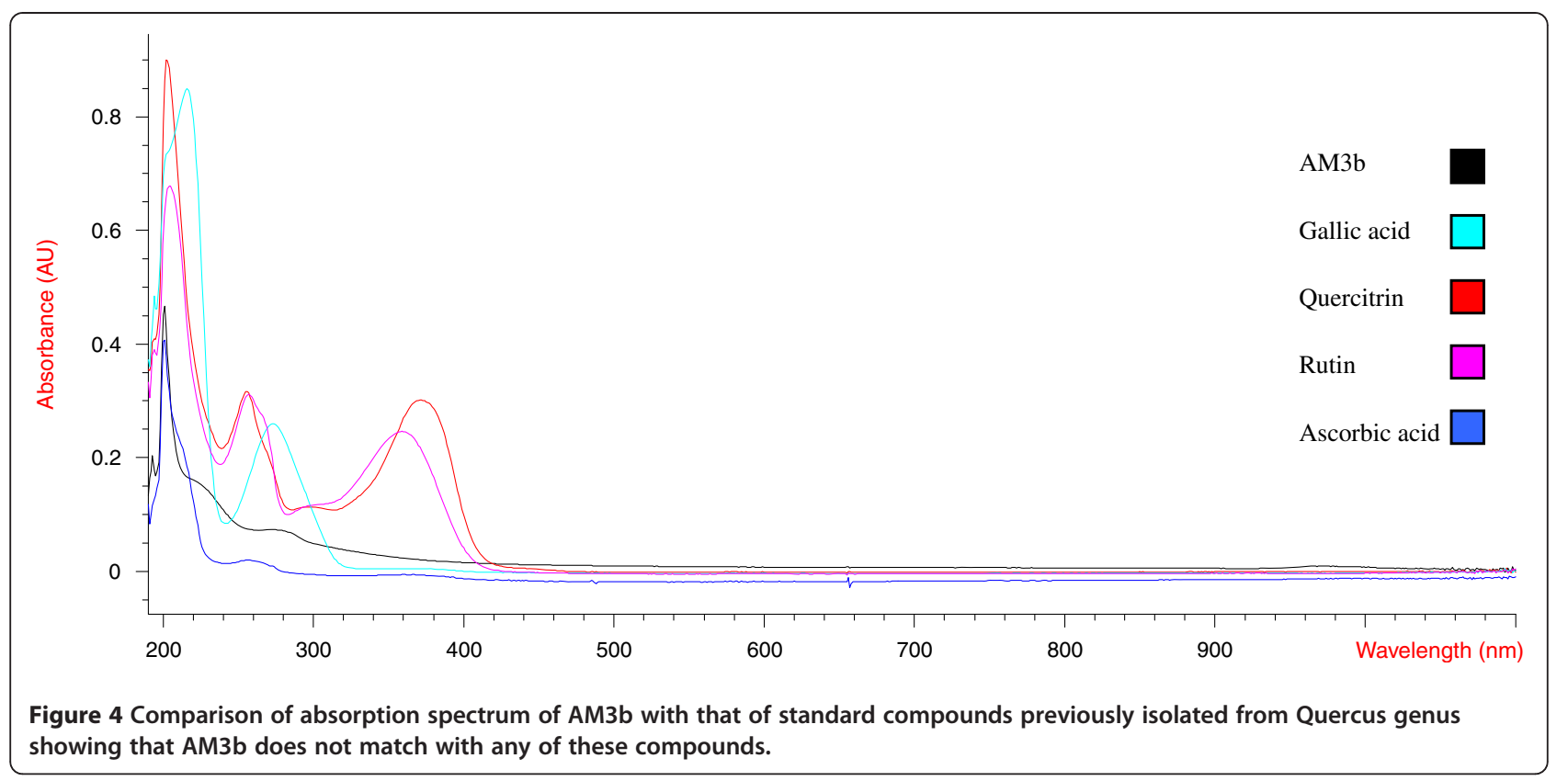

alkaloids in the three fractions in the order of, ethanol partitioned fraction $>$ acetone partitioned fraction $>50 \%$ methanol partitioned fraction. Alkaloids are commonly known antibacterial agents [32]. Therefore, our results suggested that the ethanol partitioned fraction contained maximum alkaloids which could be responsible for the highest antibacterial activity exhibited by this fraction. The polarity of a solvent plays an important role on composition of an extract and hence on its potential antibacterial activity. Similar results were reported by Berahou et al. [33] that only ethyl acetate, butanol and aqueous phases of methanol extract of Quercus ilex bark showed antibacterial activity against all the bacterial strains whereas the hexane and dichloromethane phases were almost inactive.

HPLC analysis of the most active partitioned fraction i.e., ethanol was done by isocratic RP-HPLC system consisting of Agilent 1200 series preparative pump coupled with UV diode array detector. HPLC has extensively been used for isolation and identification of active natural components components [34-36]. In this study ethanol partition fraction was eluted with acetonitrile:

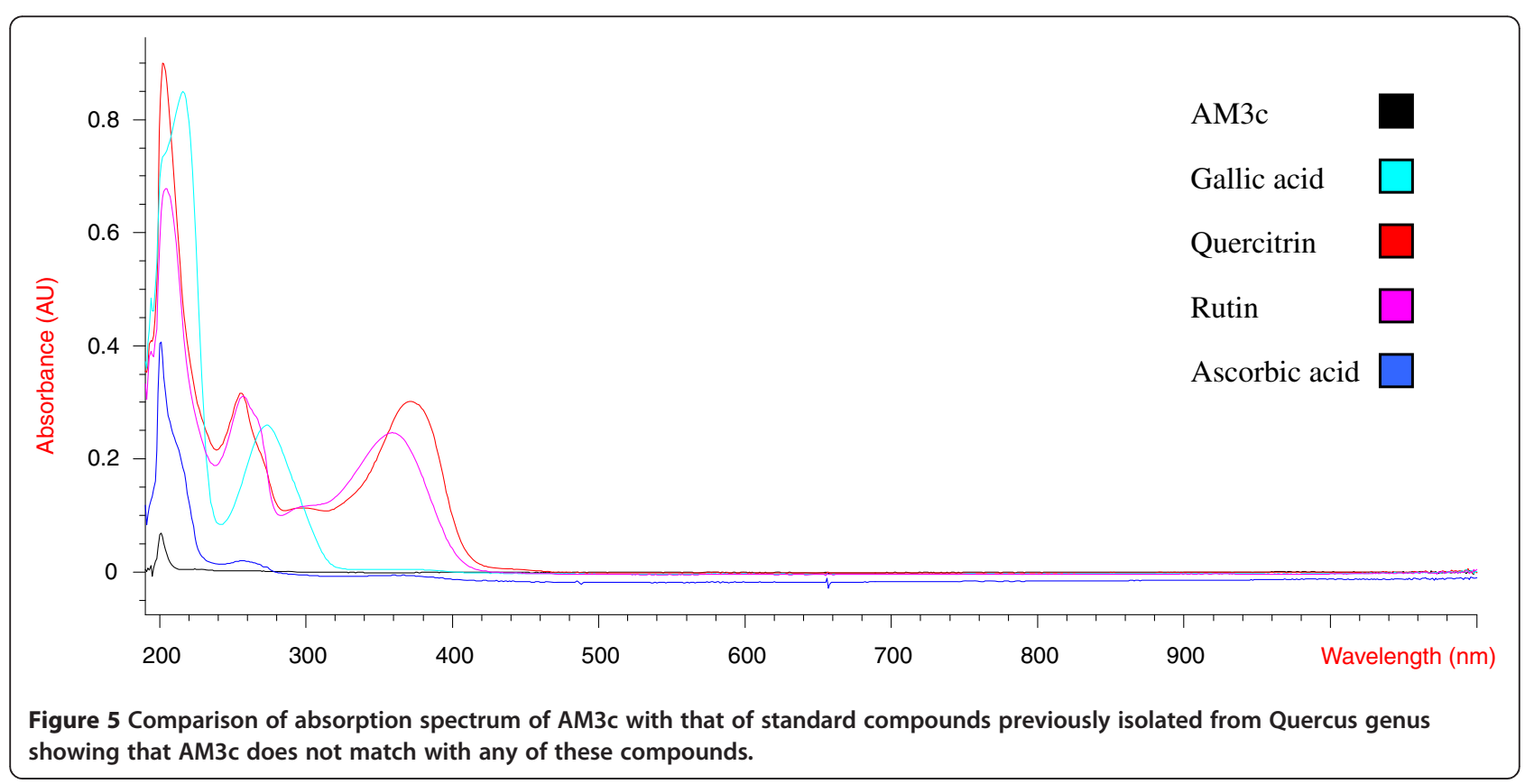


methanol (70: 30) and seven peaks were observed at $230 \mathrm{~nm}$. These seven fractions were collected at different retention times. Only one of the seven fractions i.e. AM3 had antibacterial activity against all the bacterial strains tested. AM3 showed highest antibacterial activity against S. setubal. RP- HPLC analysis of active fraction AM3 was done. When fraction AM3 was subjected to RP-HPLC analysis, three subfractions were collected at different retention times. Two of the three subfractions AM3b and AM3c showed antibacterial activity against all the bacterial strains tested.

Purified active subfractions were charaterized by comparing their absorption spectra with that of standard natural products. In the present study, four standard natural compounds used were ascorbic acid, quercitrin, gallic acid and rutin. All of them have been reprted previously from genus Quercus i.e., ascorbic acid [37], quercitrin [38], gallic acid [29] and rutin [39]. The absorption spectra of the active fractions were different from that of the standard compounds previously isolated from the Quercus genus suggesting that these are different compounds. However, structure elucidation is required to confirm their novelty. Antibacterial $[15,16]$ activity of genus Quercus was previously reported, yet antibacterial activity of $Q$. dilatata had never been checked before. Thus, this is the first report of identification and successful isolation of antibacterial compounds from this species. These compounds are effective against B. subtilis, M. leuteus, S. aureus E. coli, S. setubal and B. bronchiseptica. These bacterial strains are involved in causing many diseases like boils, cellulitis folliculitis, furuncles, carbuncles, pneumonia, meningitis, urinary tract infections etc. Furthermore, these compounds appear to be different from already known constituents of this genus and actually could be newly identified compoundsand hence can be potentially used against the above mentioned diseases.

\section{Conclusion}

This study provides new scientific information about $C$. hierosolymitana and Q. dilatata based on its biological potential and phytochemical analysis that has never been reported earlier. (A) Q. dilatata showed promising antibacterial activities. After solvent partitioning of (A) Q. dilatata, ethanol fraction was selected on the basis of results of antibacterial assay and phytochemical analysis for further fractionation through RP-HPLC analysis. The compounds purified by RP-HPLC were characterized by comparing their absorption spectra with that of the known compounds isolated from the genus Quercus and were found to be different. In order to reveal the structure of isolated compounds, NMR and crystallographic analysis are under process.

\section{Competing interests}

The author(s) declare that they have no competing interest.

\section{Acknowledgements}

We are thankful to Higher Education Commission of Pakistan for granting us funds to conduct this research.

\section{Author details}

'Department of Biochemistry, Quaid i Azam University, Islamabad, Pakistan.

${ }^{2}$ Department of Pharmacy, Quaid i Azam University, Islamabad, Pakistan.

${ }^{3}$ PMAS Arid Agriculture University, Rawalpindi, Pakistan.

\section{Authors' contributions}

All the experimental design was made by first author and in experimentation all the authors contribute equally. All authors read and approved the final manuscript.

Received: 21 January 2012 Accepted: 3 May 2012

Published: 3 May 2012

\section{References}

1. Malheiros A, Filho VC, Schmitt CB, Yunes RA, Escalante A, Svetaz L, Zacchino $S$, Monache FD: Antifungal activity of drimane sesquiterpenes from Drimys brasiliensis using bioassay-guided fractionation. J Pharm Pharmaceut Sci 2005, 8:335-339.

2. Portillo A, Vila R, Freixa B, Ferro E, Parella T, Casanova J, Cañigueral S: Antifungal sesquiterpene from the root of Vernonanthura tweedieana. $J$ Ethnopharmacol 2005, 97:49-52.

3. Zhang X, Han F, Gao P, Yu D, Liu S: Bioassay-guided fractionation of antifertility components of castorbean (Ricinus communis L.) seed extracts. Nat Prod Res 2007, 21:982-989.

4. Harraz FM, Abdel-Aziz SA: Chemical and biological studies of Chrozophora verbascifolia. Zagazig J Pharm Sci 1994, 3:72-78.

5. Adam SE, Al-Redhaiman KN, Al-Qarawi AA: Toxicity of Chrozophora obliqua in rats. Phytother Res 1999, 13:630-632.

6. Shahidi GH, Aghighi S, Nik AK: Antibacterial and antifungal survey in plants used in indigenous herbal-medicine of south east regions of Iran. J Biol Sci 2004, 4:405-412.

7. Shahidi $\mathrm{GH}$ : Anti yeast activity of some plants used in traditional herbalmedicine of Iran. J Biol Sci 2004, 4:212-215.

8. Tignokpa M, Laurens A, Mboup S, Sylla O: Popular Plants of Dakar Markets. Int J Crude Drug Res 1986, 24:75-80.

9. Etkin NL: Antimalarial plants used by Hausa in Northern Nigeria. Trop Doct 1997, 27:12-16.

10. Dong KS, Wang XQ, Dong YF: Contemporary clinical Chinese material medica. Beijing: Zhong Guo Zhong Yi Yao Press; 1998.

11. Hou JP, Jin Y: The healing power of chinese herbs and medicinal recipes. New York: Haworth Press; 2005.

12. Abourashed E, El-Alfy A, Khan I, Walker L: Ephedra in perspective-a current review. Phytother Res 2003, 17:703-712.

13. Ratera E, Ratera N: Plants flora Argentina employed in folk medicine. Argentina: Editorial Southern Hemisphere; 1980.

14. Gorunović MS, Lukić PB: Pharmakognosy. Belgrade: University of BelgradeFaculty of Pharmacy; 2001.

15. Güllüce $M$, Adigüzel $A$, Öğütçü $H$, Şengül $M$, Karaman I, Şahin F: Antimicrobial effects of Quercus ilex L. extract. Phytother Res 2004, 18:208-211.

16. Andrensek S, Simonovska B, Vovk I, Fyhrquist $P$, Vuorela H, Vuorela P: Antimicrobial and antioxidative enrichment of oak (Quercus robur) bark by rotation planar extraction using ExtraChrom. Int J Food Microbiol 2004, 92:181-187.

17. Al-Mustafa AH, Al-Thunibat OY: Antioxidant activity of some Jordanian medicinal plants used traditionally for treatments of diabetes. Pak J Biol Sci 2008, 11:351-358.

18. Chevolleau S, Mallet JF, Debal A, Ucciani E: Antioxidant activity of mediterranean plant leaves: Occurrence and antioxidative importance of a-tocopherol. J Am Oil Chem Soc 1993, 70:807-809.

19. McCune LM, Johns T: Antioxidant activity in medicinal plants associated with the symptoms of diabetes mellitus used by the indigenous peoples of the North American boreal forest. J Ethnopharmacol 2002, 82:197-205. 
20. Gharzouli K, Khennouf S, Amira S, Gharzouli A: Effects of aqueous extracts from Quercus ilex L. root bark, Punica granatum L. fruit peel and Artemisia herba-alba Asso leaves on ethanol-induced gastric damage in rats. Phytother Res 1999, 13:42-45.

21. Umachigi SP, Jayaveera KN, Kumar CKA, Kumar GS, Swamy BMV, Kumar DVK: Studies on wound healing properties of Quercus infectoria. Trop I Pharma Res 2008, 7:913-919.

22. Choudhary MI, Shahwar D, Parveen Z, Jabbar A, Ali I, Rahman AU: Antifungal steroidal lactones from Withania coagulance. Phytochemistry 1995, 40:1243.

23. Ansari FL, Nazir S, Noureen H, Mirza B: Combinatorial synthesis and antibacterial evaluation of an indexed chalcone library. Chem Biodiverse 2006, 2:1656-1664

24. Rios JL, Recio MC, Vilar A: Screening methods for natural products with antimicrobial activity: A review of literature. J Ethnopharmacol 1988, 23:127-149.

25. Edeoga HO, Okwu DE, Mbaebie BO: Phytochemical constituents of some Nigerian medicinal plants. Afr J Biotechnol 2005, 4:685-688.

26. Parekh J, Chanda SV: In vitro antimicrobial activity and phytochemical analysis of some Indian medicinal plants. Turk J Biol 2007, 31:53-58.

27. Vileges JH, DeMarchi E, Lancas FM: Extraction of low polarity compounds (with emphasis on coumarin and kaurenoic acis) from Mikania glomerata (guaco) leaves. Phytochem Anal 1997, 8:266-270.

28. Makkar HPS, Singh B, Dawra RK: Effect of tannin-rich leaves of oak (Quercus incana) on various microbial enzyme activities of the bovine rumen. Br J Nutr 1988, 60:287-296.

29. Serit M, Okubo T, Su RH, Hagiwara N, Kim M, Iwagawa T, Yamamoto T: Antibacterial compounds from Oak, Quercus acuta Thunb. Agric Biol Chem 1991, 55:19-23.

30. Voravuthikuchai SP, Limsuwan S, Mitchell H: Effects of Punica granatum pericarps and Quercus infectoria and nutgalls on cell surface hydrophobicity and cell survival of Helicobacter pylori. J Health Sci 2006, 52:154-159.

31. Voravuthikunchai SP, Chusri S, Suwalak S: Quercus infectoria Oliv. Pharm Biol 2008, 46:367-372.

32. Wirasathien L, Boonarkart C, Pengsuparp T, Suttisri R: Biological activities of alkaloids from Pseuduvaria setosa. Pharm Biol 2006, 44:274-278.

33. Berahou A, Auhmani A, Fdil N, Benharref A, Jana M, Gadhi CA: Antibacterial activity of Quercus ilex bark's extracts. J Ethnopharmacol 2007, 112:426-429.

34. Gruber JW, Siebert DJ, Marderosian AHD, Hock RS: High performance liquid chromatographic quantification of salvinorin A from tissues of Salvia divinorum Epling and Játiva-M. Phytochem Anal 1999, 10:22-25.

35. Proestos C, Chorianopoulos N, Nychas GJE, Komaitis M: RP HPLC analysis of the phenolic compounds of plant extracts, investigation of their antioxidant capacity and antimicrobial activity. J Agric Food Chem 2005, 53:1190-1195.

36. Qu LP, Fan GR, Peng JY, Mi HM: Isolation of six isoflavones from Semen sojae praeparatum by preparative HPLC. Fitoterapia 2007, 78:200-204.

37. García-Plazaola Jl, Artexte U, Dunabeitia MK, Becerril JM: Role of photoprotective systems of holm oak (Quercus ilex) in the adaptation to winter conditions. J Plant Physiol 1999, 155:625-630.

38. Parker J: Phenolics in black oak bark and leaves. J Chem Ecol 1977, 3:489-496.

39. Joshi VK, Shah PK, Nath AK: The influence of addition of wood chips to peach wine on quantity and type of phenols. Alimentaria 2000, 312:23-26.

doi:10.1186/1476-0711-11-11

Cite this article as: Jamil et al.: Isolation of antibacterial compounds from Quercus dilatata $\mathrm{L}$. through bioassay guided fractionation. Annals of Clinical Microbiology and Antimicrobials 2012 11:11.

\section{Submit your next manuscript to BioMed Central and take full advantage of:}

- Convenient online submission

- Thorough peer review

- No space constraints or color figure charges

- Immediate publication on acceptance

- Inclusion in PubMed, CAS, Scopus and Google Scholar

- Research which is freely available for redistribution

Submit your manuscript at www.biomedcentral.com/submit 